\title{
Pengembangan Multimedia Interaktif Mata Pelajaran Bahasa Arab Materi Profesi Bagi Siswa Kelas VIII SMP IT Al-Huda Wonogiri
}

\author{
Muhammad Luqman Hakim ${ }^{1}$ \\ Asrowi $^{2}$ \\ Muhammad Akhyar ${ }^{3}$
}

\begin{abstract}
This research is a Recearch and Development $(R \& D)$ by using ASSURE model. The purpose of this research is 1) produce interactive multimedia, which are appropriate with the students' need 2) to enhance students' vocabulary of Arabic language. The data were collected by observation, interview, questionnaire, and document. The result of this research is 1) test of media expert showed the product is considered very good, the result is $4.60,2)$ expert of the material showed that multimedia interactive is considered good, with result 3,97 3) the test of one to one showed the average score of 4,26 means the product is considered very good, the test of small group evaluation showed the avarage score of 4,38 is considered very good, and the test of field evaluation showed the average score of 4,42 means the product is very good, the conclusion is product can be appliying in learning.
\end{abstract}

Keywords: development, interactive multimedia, learning, vocabulary, arabic language.

\begin{abstract}
Abstrak: Penelitian ini merupakan penelitian Recearch and Development $(R \& D)$ dengan menggunakan model ASSURE. Tujuan dari penelitian ini adalah 1) memproduksi multimedia interaktif yang sesuai dengan kebutuhan siswa, 2) meningkatkan penguasaan kosakata bahasa Arab siswa dengan menggunakan multimedia Interaktif. Pengumpulan data dilakukan dengan obervasi, wawancara, lembar penilaian, dan dokumen. Hasil dari peneilitian ini ialah: 1) uji coba ahli media terhadap multimedia pembelajaran interaktif menunjukkan kategori sangat baik, nilai rata-rata yang diperoleh adalah 4,60. 2) uji coba ahli materi menunjukkan multimedia pembelajaran interaktif memiliki penilaian baik, dengan nilai rata-rata 3,97 4. 3) uji coba satu-satu mendapat skor rata-rata sebesar 4,26 termasuk kategori sangat baik, uji coba terbatas memperoleh skor rata-rata 4,38 termasuk kategori sangat baik, dan uji coba luas 4,42 dengan kategori sangat baik, maka dapat disimpulkan bahwa multimedia interaktif layak diterapkan.
\end{abstract}

Kata Kunci: pengembangan, multimedia interaktif, pembelajaran, kosakata, bahasa arab.

\footnotetext{
${ }^{1}$ Muhammad Luqman Hakim, Pascasarjana Teknologi Pendidikan, Universiitas Sebelas Maret, E-mail: manluq47@mail.com, Contact Person:085642191254

${ }^{2}$ Asrowi, Dosen, Pascasarjana Teknologi Pendidikan, Universiitas Sebelas Maret, E-mail: asrowi@yahoo.com.

${ }^{3}$ Muhammad Akhyar, Dosen, Pascasarjana Teknologi Pendidikan, Universiitas Sebelas Maret, E-mail: makhaliya@yahoo.com.
} 


\section{PENDAHULUAN}

Berdasarkan peraturan Menteri Agama Republik Indonesia Nomor 2 Tahun 2008 mata pelajaran Bahasa Arab merupakan suatu mata pelajaran yang diarahkan untuk mendorong, membimbing, mengembangkan, dan membina kemampuan serta menumbuhkan sikap positif terhadap bahasa Arab baik represif maupun produktif. Kemampuan represif yaitu kemampuan untuk memahami pembicaraan orang lain dan memahami bacaan. Kemampuan produktif yaitu kemampuan menggunakan bahasa sebagai alat komunikasi baik secara lisan maupun tulis.

Secara umum, kecakapan bahasa adalah salah satu tujuan kurikulum bahasa Arab yang ditulis dalam dokumen kurikulum. Zulhanan (2015: 76-78) meyampaikan bahwa secara umum pembelajaran bahasa Arab di sekolah diarahkan pada penguasaan keempat keterampilan berbahasa (Al-Maharoh Al-Arba'ah) yang meliputi keterampilan mendengar (Al-maharah Al-Istima'), keterampilan berbicara (Al-maharah Al-Kalam), keterampilan membaca (Al-Maharah Al-Qira'ah) serta keterampilan menulis (AlMaharah Al-Kitabah). Namun keterampilanketerampilan tersebut tidak akan tercapai tanpa penguasaan kosakata yang baik, karena kualitas keterampilan berbahasa seseorang bergantung kepada kuantitas dan kualitas kosakata yang dimilikinya. Semakin kaya kosakata yang kita miliki, semakin besar pula kemungkinan kita terampil berbahasa. (Tarigan, 2011: 2).

Maskor, Baharudin, Lubis \& Yusuf (2016, 482) menyatakan bahwa efisiensi dalam penggunaan bahasa terletak pada penggunaan kosakata yang luas dan bermakna, yang membutuhkan akuisisi dan pengetahuan kosakata.
Pentingnya penguasaan kosakata dalam mempelajari bahasa lain diilustrasikan oleh Wilkins (1972) dalam Ghanbaran \& Ketabi (2014: 389) sebagai "Without grammar, little can be conveyed, without vocabulary, nothing can be conveyed". Pada dasarnya tanpa menguasai tata bahasa, sedikit yang bisa disampaikan, akan tetapi tanpa menguasai kosakata, tidak ada yang bisa disampaikan. Pengetahuan kosakata sangat penting untuk keberhasilan akademik siswa. Ini sangat berkorelasi dengan prestasi akademik dan pemahaman membaca secara keseluruhan dan berkontribusi pada prestasi siswa (Kenedy, 2017: 213).

Dalam beberapa tahun terakhir, akuisisi kosakata bahasa kedua telah menjadi topik diskusi yang semakin menarik bagi para peneliti, guru, perancang kurikulum, ahli teori, dan lainnya yang terlibat dalam pembelajaran bahasa kedua. Cheryl Zimmerman dalam Coady (1997: 77) mengawali survei sejarah metode pengajaran kosakata. Kosakata adalah pusat dari bahasa, dan termasuk kata-kata yang sangat penting bagi pembelajar bahasa. Namun demikian, pengajaran dan pembelajaran kosakata telah dinilai rendah di bidang akuisisi bahasa kedua di seluruh tahapan hingga hari ini.

Guru sadar bagaimana komunikasi terhenti ketika pelajar tidak memiliki kata-kata yang memadai. Sebaliknya guru tidak percaya bahwa pengajaran kosakata harus ditunda sampai tata bahasa dikuasai. Di kelas-kelas terbaik, baik tata bahasa maupun kosakata tidak pernah diabaikan (Allen, 1983:5).

Kosakata dalam bahasa Arab atau yang disebut dengan mufradat, merupakan himpunan kata-kata atau khazanah kata yang diketahui oleh 
seseorang atau entinitas lain yang merupakan bagian dari bahasa tertentu. Kosakata merupakan salah satu dari tiga unsur bahasa yang harus dikuasai, kosakata ini digunakan dalam bahasa tulis maupun bahasa lisan, dan merupakan salah satu alat untuk mengembangkan kemampuan berbahasa Arab seseorang (Mustafa, 2011: 61). Dalam kamus online Al-Ma'any, mufradat memiliki makna seluruh kata-kata yang terdapat di dalam bahasa Arab.

Thornbury (2002: 23) menyatakan bahwa belajar kosakata tidak hanya mempelajari jumlah kata, tetapi juga mengingat dan menggunakannya. Belajar kosakata adalah mengingat dan menggunakannya dalam kehidupan nyata. Mempelajari kosa kata adalah salah satu langkah pertama belajar bahasa kedua, perolehan kosakata baru adalah proses berkelanjutan.

Bahasa arab telah lama berkembang di Indonesia, namun tampaknya mempelajari bahasa Arab sampai sekarang tidak terlepas dari problematika. Salah satunya adalah problem dalam hal menggunakan metode pada saat proses pembelajaran bahasa Arab berlangsung. Mereka pembelajaran bahasa Arab dengan menggunakan pengantar Indonesia, umumnya para pengajar menggunakan metode gramatika dan terjemah (tariqah al-qawaid wa at-tarjamah) (Mu'in, 2015: 41).

Fakta di lapangan, pembelajaran bahasa Arab masih menggunakan metode gramatika dan terjemah (tariqah al-qawaid wa at-tarjamah). Penggunaan metode tersebut bukan merupakann kesalahan, akan tetapi metode tersebut cenderung kurang efektif bila diterapkan pada pembelajaran bahasa Arab. Westomi, Ibrahim \& Sukardjo (2018: 137) menerangkan proses pembelajaran menekankan agar bagaimana para peserta didik aktif dan serta berinteraksi dengan pendidik dan sumber belajar agar dapat mengembangkan dan mengoptimalkan potensi yang dimiliki oleh setiap peserta didik dalam suatu lingkungan belajar yang dapat mendukung proses pembelajaran berjalan dengan baik, efektif dan efisien.

Hal tersebut dapat dilihat dari hasil studi pendahuluan, peneliti mendistribusikan tes kepada 27 siswa tentang penguasaan kosakata bahasa Arab, hasilnya 25\% dari siswa memiliki nilai ketuntasan yang baik, namun $75 \%$ belum dikatakan tuntas. Hal ini begitu memprihatinkan mengingat sekolah bersistem boarding school memiliki kelebihan dalam mengontrol siswanya untuk memiliki keterampilan bahasa Arab.

Pembelajaran bahasa Arab sesungguhnya sangat menghendaki keterlibatan siswa secara langsung. Hendaknya diterapkan model pembelajaran interaktif yakni model pembelajaran yang melibatkan siswa secara aktif dan pasif. Model pembelajaran interaktif ini dimaksudkan untuk memperkenalkan kepada peserta didik mengenai sejumlah pengetahuan materi-materi tertentu yang sudah diajarkan kepada mereka, sekaligus menghadapkan peserta didik pada sejumlah masalah untuk dipecahkan secara bersama-sama (Wa Muna, 2011: 19).

Studi mengklaim bahwa, Bahasa Arab dapat dikuasai lebih bermakna jika guru memanfaatkan suara, pola, gerakan, simbol dan perpaduan multimedia dalam pelajaran seharihari. (Faryadi, 2007: 1). Akan tetapi pembelajaran bahasa Arab masih kurang memanfaatkan alat bantu belajar mengajar meskipun kita sudah masuk abad ke-21 dengan penciptaan berbagai aplikasi multimedia canggih dari Web1.0 hingga 
Web 3.0. Analisis kebutuhan diperlukan untuk mendesain, mengembangan produk dan sebagai alat kerangka kerja penelitian (Sahrir, 2011: 137).

Bahasa memiliki banyak bentuk: lisan, tulisan, kinesik (bahasa tubuh). Sehingga guru membutuhkan banyak teknologi yang dapat dimiliki untuk menyajikan bahasa secara efektif dalam konteks di mana pembelajaran akan berlangsung (Rivers, 1987: 157).

Melihat permasalahan di atas, peneliti ingin mencoba memberikan kontribusi pada pembelajaran bahasa Arab yaitu melalui pengembangan multimedia pembelajaran interaktif bahasa Arab. Multimedia pembelajaran interaktif merupakan media pembelajaran yang diharapkan dapat meningkatkan pemahaman dengan cepat karena didukung pembelajaran yang menarik dan membuat siswa menjadi aktif. Jadi, pada saat pembelajaran kosakata bahasa Arab siswa menggunakan multimedia interaktif untuk menambah semangat dalam mempelajari bahasa Arab karena dikemas dengan menarik dan tidak monoton sehingga diharapkan mereka dapat mengingat kosakata yang berhubungan dengan materi yang terdapat di multimedia pembelajaran interaktif, yang mana penguasaan kosakata merupakan kunci seseorang untuk terampil dalam berbahasa.

Secara umum manfaat yang dapat diperoleh adalah proses pembelajaran lebih menarik, lebih interaktif, jumlah waktu mengajar dapat dikurangi, kualitas belajar siswa dapat ditingkatkan dan proses belajar mengajar dapat dilakukan dimana dan kapan saja, serta sikap belajar siswa dapat ditingkatkan (Daryanto, 2013: $52)$.
Pengembangan multimedia pembelajaran kosakata didukung oleh teori dual-coding Paivio (1986), yang mengemukakan keberadaan sistem terpisah untuk memproses informasi verbal dan nonverbal. Menurut teori ini (Silverman \& Hines 2009: 305), ketika informasi disampaikan baik secara verbal maupun nonverbal, kedua sistem ini saling mendukung dan memungkinkan penarikan informasi yang lebih besar. Peningkatan multimedia dapat memberi anak-anak informasi nonverbal lebih kuat daripada yang disajikan dalam bentuk gambar dalam buku cerita dan memungkinkan anak-anak untuk menggunakan lebih efektif sistem pemrosesan nonverbal mereka.

Multimedia interaktif adalah suatu multimedia yang dilengkapi dengan alat pengontrol yang dapat dioperasikan oleh pengguna, sehingga pengguna dapat memilih apa yang dikehendaki untuk proses selanjutnya (Daryanto, 2013: 51). Kekuatan materi melalui komputer adalah kemampuan mereka untuk menciptakan situasi di mana peserta didik bekerja sendiri atau dalam kelompok dan berinteraksi dengan materi pembelajaran dan bahan referensi (Shao, 2012: 203).

Penelitian yang dilakukan Xue Shi (2007: 21) menjelaskan bahwa menurut analisis data eksperimental, pembelajaran kosakata yang didukung multimedia berbasis komputer lebih efektif daripada metode tradisional. Hasilnya menunjukkan bahwa, melalui multimedia berbasis komputer, pengetahuan bisa dipelajari lebih cepat dan dipertahankan lebih lama pada ingatan siswa.

Khiyabani, Ghonsooly, \& Ghabanchi (2014: 1) menyarankan menggunakan multimedia 
lebih efektif dalam memperoleh dan mempelajari kosakata yang tidak diketahui, dari pada metode tradisional. Dan berpengaruh positif terhadap retensi pengetahuan kosa kata. Oleh karena itu, penggunaan multimedia merupakan jembatan menuju ke pemahaman yang lebih mendalam.

Nanchao (2005) dalam Yujie Chang (2017: 294) mengemukakan bahwa teknologi multimedia dapat mempromosikan pembelajar kosakata. Studi psikolog membuktikan bahwa orang memperoleh informasi melalui auditori dan rangsangan visual, di antaranya $11 \%$ melalui pendengaran dan $83 \%$ melalui informasi visual. Teknologi multimedia dapat memberi siswa video, gambar, dan teks yang kaya, membuat mata mereka tertarik dan telinga bekerja bersama, untuk mengidentifikasi dan mengekstrak kosakata, sehingga mempromosikan pengajaran kosakata baru.

Ren (2013: 263) menemukan bahwa pengajaran kosakata bahasa Inggris dengan menggunakan teknologi multimedia dapat lebih merangsang siswa untuk belajar kosakata bahasa Inggris, dengan hasil pengajaran yang lebih baik daripada pengajaran kosakata bahasa Inggris secara tradisional.

Melalui multimedia pembelajaran interaktif proses pembelajaran bisa lebih menarik dan menyenangkan (Joyfull learning), oleh karena itu peneliti berkeinginan memberikan kontribusi dalam pembelajaran bahasa Arab guna meningkatkan penguasaan kosakata siswa.

\section{METODE PENELITIAN}

Penelitian ini merupakan penelitian Research and Development $(R \& D)$ dengan menggunakan model ASSURE. Model desain
ASSURE menekankan pada faktor pemanfaatan media dan bahan ajar yang direncanakan dengan baik, yang membuat siswa belajar secara aktif. Model ASSURE terdiri dari enam tahapan, yaitu: 1) Analyze Learner (analisis karakteristik siswa), 2) State Objective (menetapkan tujuan pembelajaran), 3) Select Method Media and Materials (memilih metode, media dan bahan ajar) 4) Utilize Materials (memanfaatkan bahan ajar), 5) Require Learner Participation (melibatkan siswa dalam kegiatan belajar), dan 6) Evaluate and Revise (evaluasi dan revisi) (Pribadi, 2011: 31-34).

Teknik pengumpulan data yang digunakan peneliti ialah dengan obervasi, wawancara, lembar penilaian dan dokumen. Untuk lembar penilian pada penelitian ini menggunakan skala likert, setiap item instrumen terbagi menjadi 5 kategori yaitu; sangat baik, baik, cukup, kurang baik, sangat kurang baik, dengan skala 1-5 (Sugiyono, 2011: 135).

Kemudian data kuantitatif tersebut dikonversikan menjadi data kualitatif menggunakan tabel berikut ini:

Tabel 1. Konversi Data Kuantitatif ke Data Kualitatif (Sudijono, 2005: 132).

\begin{tabular}{|c|c|c|}
\hline Interval Skor & Nilai & Kriteria \\
\hline $\mathrm{X} \geq 4,21$ & 5 & Sangat baik \\
\hline $3,40<\mathrm{X} \leq 4,21$ & 4 & Baik \\
\hline $2,60<\mathrm{X} \leq 3,40$ & 3 & Cukup \\
\hline $1,79<\mathrm{X} \leq 2,60$ & 2 & Kurang baik \\
\hline $\mathrm{X} \leq 1,79$ & 1 & Sangat kurang \\
\hline
\end{tabular}

Sebelum produk benar-benar diterapkan pada pembelajaran perlu diuji coba, hal tesebut bertujuan untuk menguji kelayakan produk. Uji kelayakan dilakukan oleh pakar materi dan media serta uji coba pengguna. Terdapat tiga tahapan uji 
coba pengguna untuk evaluasi materi yang dikembangkan, yaitu uji coba satu satu (one to one), uji coba kelompok kecil (small group evaluation), dan uji coba kelompok besar (field evaluation) (Dick, Carey \& Carey, 2009: 261)

\section{HASIL}

Pengembangan multimedia pembelajaran interaktif ini dilakukan dengan beberapa tahapan, mengumpulkan permasalahan yang terjadi berdasarkan hasil wawancara, observasi, dan dokumen.

\section{Analisis Karakteristik Siswa (Analyze Learner)}

Karakteristik umum siswa kelas VIII SMP IT Al Huda memiliki umur sekitar 12-13 tahun, karakteristik umum pada usia tersebut ialah siswa aktif pada saat dilibatkan dalam pembelajaran, siswa cenderung kepada pembelajaran yang menyenangkan dan tidak membosankan. Namun, apabila mereka menghadapi kejenuhan dalam belajar, siswa cenderung mengobrol dengan temannya.

Pada mata pelajaran bahasa Arab siswa sedikit banyak sudah mengetahui nama-nama (kosakata) benda yang ada disekitar mereka, seperti; kelas, meja, buku, dan lain sebagainya. Akan tetapi kosakata tersebut belum dapat mereka gunakan sebagai bahan untuk menggunakan bahasa Arab sebagai alat komunikasi karena penguasaan kosakata yang mereka miliki terbatas hanya pada benda-benda disekitar mereka.

Ketersediaan fasilitas di sekolah seperti laptop, LCD, internet, sound system dan lainnya juga belum dimanfaatkan secara maksimal sebagai sarana untuk mendukung proses pembelajaran bahasa Arab. Untuk meminimalisir kejenuhan siswa dalam pembelajaran dan upaya pemanfaatan fasilitas di sekolah, maka dikembangkan sebuah multimedia interaktif.

Menetapkan Tujuan Pembelajaran (State Objective)

Tujuan dari perumusan tujuan pembelajaran agar siswa mengetahui kompetensi yang akan dicapai oleh setiap pelajar setelah kegiatan pembelajaran berlangsung, dan mempermudah penilaian yang akurat tentang pembelajaran siswa. Kompetensi dasar, dan tujuan pembelajaran yang digunakan dalam desain multimedia interaktif berpedoman pada silabus dan RPP yang digunakan di sekolah. Adapun materi yang akan dikembangkan pada multimedia interaktif adalah tentang profesi (المهنة).

Tabel 2. Rangkuman Tujuan Pembelajaran

\begin{tabular}{|c|c|}
\hline $\begin{array}{l}\text { Kompetensi } \\
\text { Dasar (KD) }\end{array}$ & $\begin{array}{l}2.2 \text { Memahami bunyi, makna, } \\
\text { dan gagasan dari kata, frase, } \\
\text { kalimat Arab sesuai dengan } \\
\text { struktur kalimat yang } \\
\text { berkaitan dengan topik } \\
\text { baik secara lisan maupun } \\
\text { tertulis. }\end{array}$ \\
\hline $\begin{array}{l}\text { Tujuan } \\
\text { Pembelajaran }\end{array}$ & 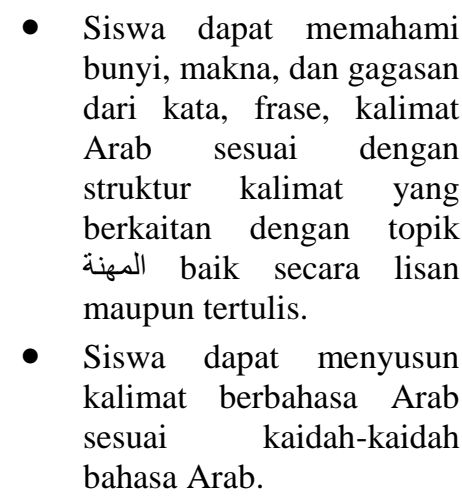 \\
\hline
\end{tabular}

Produksi Media (Select Method Media and Materials)

Dengan menggunakan model pengembangan ASSURE, guru bisa menggunakan media yang sudah ada untuk diterapkan di kelas. Guru juga bisa mengembangkan sebuah media, jika media yang 
sudah ada belum sesuai dengan materi yang akan disampaikan. Untuk mempermudah dalam memproduksi mulitmedia perlu menyusun flowchart media yang akan di produksi. Flowchart ini berisi sub-materi apa yang akan ditampilkan dalam multimedia. Berikut adalah bagan flowchart yang dirancang dalam multimedia yang akan dikembangkan:

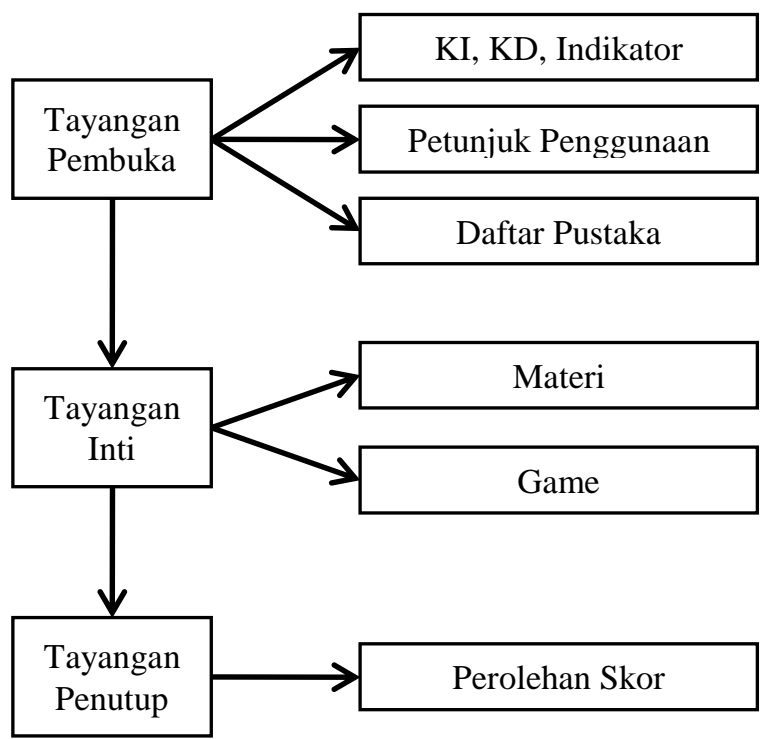

Gambar 1. Model Flowchart Pengembangan Multimedia Interaktif

Multimedia innteraktif ini terdari dari 3 tayangan, tayangan pembuka, tayangan inti, dan tayangan penutup. Pada materi multimedia terdiri dari materi kosakata, membaca, mendengar, dan kaidah-kaidah dalam bahasa Arab. Untuk materi Game terdiri dari mencocokkan gambar, menyusun huruf, dan pilihan ganda.

Produk akhir dari multimedia interaktif berupa CD. Dengan keping CD menjaga file di dalam tidak terhapus jika suatu waktu pengguna lupa mendelete. Sebelum memanfaatkan multimedia yang telah dipilih dan diproduksi, langkah yang harus dilakukan adalah melakukan validasi dan uji coba terhadap produk yang telah diproduksi. Tahap validasi dan uji coba ini bertujuan untuk menentukan kelayakan produk yang telah dikembangkan, apakah produk tersebut layak untuk diimplementasikan dalam pembelajaran atau belum. Validasi produk ini dilakukan oleh ahli dan pengguna, validasi ahli dilakukan oleh ahli materi dan ahli media yang dianggap kompeten dalam bidang materi dan media yang dikembangkan.

Kelayakan Multimedia interaktif Pembelajaran Media yang merupakan produk awal divalidasi oleh ahli materi dan ahli media. Ahli materi tersebut diantaranya adalah 3 orang dosen Pendidikan Bahasa Arab, dan instrumen yang digunakan adalah lembar penilaian. Ahli materi memvalidasi aspek kelayakan isi, penyajian, dan bahasa dari materi yang dikembangkan. Ahli media yang memberikan penilaian adalah 2 orang dosen ahli media. Ahli materi dalam penelitian ini adalah Prof. Dr. Nunuk Suryani, M.Pd., dan Dr. Deny Tri Ardianto, S.Sn., Dipl. Art yang merupakan dosen dari Universitas Sebelas Maret. Ahli media melakukan validasi terhadap aspek tampilan dan pemrogaman. Aspek tampilan terkait dengan penggunaan huruf dalam teks, pemilihan warna, penggunaan audio pengiring, dan pemilihan gambar. Sementara untuk aspek pemrogaman lebih ditekankan pada operasional penggunaan media.

Tabel 3. Rekapitulasi Hasil Validasi Ahli

\begin{tabular}{|c|c|c|c|}
\hline Validator & $\begin{array}{c}\text { Jumlah } \\
\text { Skor }\end{array}$ & Rerata & Kriteria \\
\hline Materi & $\mathbf{3 6 2}$ & $\mathbf{3 , 9 7}$ & Baik \\
\hline Media & $\mathbf{2 2 9}$ & $\mathbf{4 , 6 0}$ & Sangat Baik \\
\hline
\end{tabular}

Dari tabel di atas, menunjukkan bahwa hasil hasil validasi ahli materi yang meliputi aspek kelayakan isi, penyajian, dan bahasa dari materi yang dikembangkan menunjukkan multimedia 
interaktif pembelajaran ini memiliki penilaian baik. Jumlah skor yang diperoleh 362 dan rerata skor 3,97 yang kemudian dikonversikan dengan skala 5 sehingga diperoleh hasil baik. Ada beberapa masukan yang diberikan oleh ahli materi yaitu banyaknya kesalahan dalam penulisan harokat pada teks bahasa Arab di multimedia interaktif, penambahan kalimat pada materi percakapan dan beberapa gambar yang tidak sesuai dengan karakteristik siswa kelas VIII.

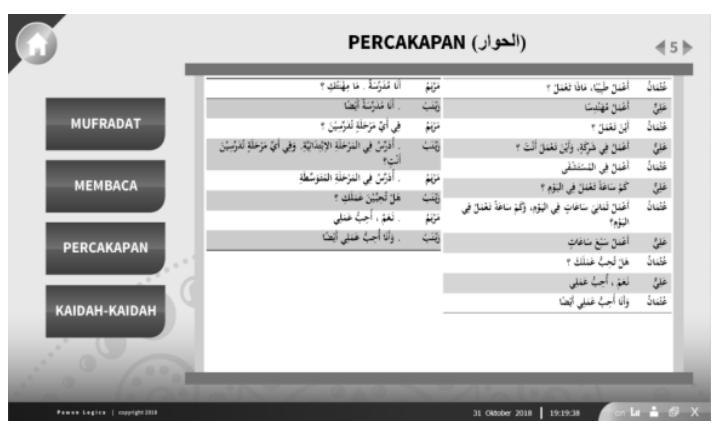

Gambar 2. Photoscreen sebelum penambahan materi percakapan.

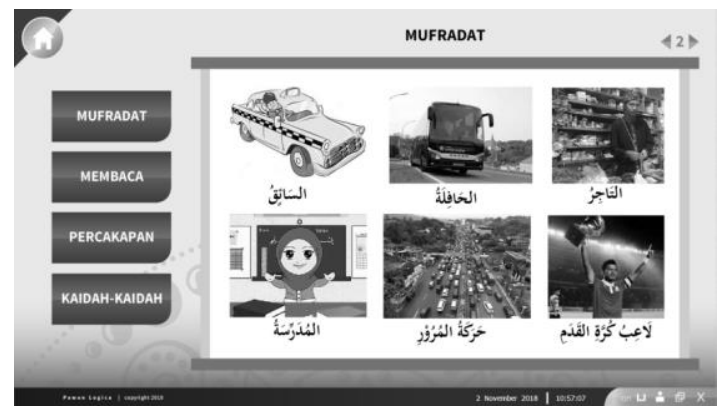

Gambar 3. Gambar ilustrasi yang tidak sesuai dengan karakteristik siswa kelas VIII.

Sedangkan validasi ahli media ditinjau

dari aspek tampilan dan pemrogaman menunjukkan multimedia pembelajaran interaktif ini memiliki penilaian sangat baik. Jumlah skor yang diperoleh 229 dan rerata skor 4,60 yang kemudian dikonversikan dengan skala 5 sehingga diperoleh hasil sangat baik. Namun, ada beberapa masukan yang diberikan oleh ahli media mengenai multimedia pembelajaran interaktif yang dikembangkan yaitu perlu adanya dubbing/suara pada materi membaca sehingga siswa bisa mengikuti teks tersebut.

Uji coba Satu - Satu

Pada uji coba satu-satu yang digunakan sebanyak 3 siswa. Siswa tersebut akan menggunakan dan menilai multimedia interaktif yang dikembangkan sebelum diterapkan pada proses pembelajarannya. Setelah siswa tersebut mengaplikasikan multimedia interaktif tersebut, siswa diberikan lembar penilaian untuk diisi. Penilaian yang dilakukan oleh siswa ini berupa angket dan yang dinilai dari aspek tampilan, penyajian materi, dan manfaat pada multimedia interaktif. Jumlah skor yang diperoleh 317 dan rerata skor 4,26 yang kemudian dikonversikan dengan skala 5 sehingga diperoleh hasil sangat baik Hasil dari uji satu-satu dipaparkan pada tabel di bawah ini:

Tabel 4. Rekapitulasi Hasil Uji Coba Satu-Satu

\begin{tabular}{ccc}
\hline $\begin{array}{c}\text { Jumlah } \\
\text { Skor }\end{array}$ & $\begin{array}{c}\text { Rerata } \\
\text { Skor }\end{array}$ & Kriteria \\
\hline 317 & 4,26 & Sangat Baik \\
\hline
\end{tabular}

Uji Coba Kelompok Kecil

Pada tahap uji coba kelompok kecil, multimedia pembelajaran interaktif diujicobakan kepada 10 orang siswa yang dapat mewakili populasi. Uji coba ini bertujuan untuk mengetahui mengenai kelayakan produk dari aspek tampilan, penyajian materi, dan manfaat pada multimedia interaktif. Penilaian pada uji coba kelompok kecil menunjukkan hasil yang sangat baik. Jumlah skor yang diperoleh 987 dan rerata skor 4,38 yang kemudian dikonversikan dengan skala 5 sehingga diperoleh hasil sangat baik. Hasil tersebut dapat dilihat pada tebel di bawah ini: 
Tabel 5. Rekapitulasi Hasil Uji Coba Kelompok Kecil

\begin{tabular}{ccc}
\hline $\begin{array}{c}\text { Jumlah } \\
\text { Skor }\end{array}$ & $\begin{array}{c}\text { Rerata } \\
\text { Skor }\end{array}$ & Kriteria \\
\hline 1091 & 4,38 & Sangat Baik \\
\hline
\end{tabular}

Hasil Uji Coba Kelompok Besar

Uji ini dilakukan untuk mengetahui tanggapan siswa mengenai kelayakan produk dari aspek tampilan, penyajian materi, dan manfaat pada multimedia interaktif yang sudah dikembangkan dan melalui tahap revisi sehingga produk yang diujikan sudah layak untuk digunakan. Dalam tahap ini, dipilih 30 anak dengan berbagai karakteristik dari kelas VIII SMP IT Al Huda. Dari angket yang didistribusikan kepada responden menunjukkan multimedia pembelajaran interaktif ini memiliki penilaian sangat baik. Jumlah skor yang diperoleh 2641 dan rerata skor 4,42 yang kemudian dikonversikan dengan skala 5 sehingga diperoleh hasil sangat baik. Hasil penilaian tersebut dapat dilihat pada tebel di bawah ini.

Tabel 6. Rekapitulasi Hasil Uji Coba Kelompok Besar

\begin{tabular}{ccc}
\hline Jumlah Skor & Rerata Skor & Kriteria \\
\hline 2641 & 4,42 & Sangat Baik \\
\hline Bila melihat & hasil & penilaian dari pakar
\end{tabular}

materi sebesar 3,97, pakar media sebesar 4,60, uji coba satu-satu sebesar 4,26, uji coba terbatas sebesar 4,38, dan uji coba luas 4,42 maka dapat disimpulkan bahwa multimedia interaktif layak dan dapat diterapkan pada pembelajaran bahasa Arab.

\section{Memanfaatkan Media (Utilize Materials)}

Setelah multimedia interaktif, divalidasi, diuji coba, dan dinyatakan layak digunakan, tahap selanjutnya adalah mengimplementasikan multimedia interaktif pada pembelajaran Bahasa Arab kelas VIII. Multimedia interaktif diimplementasikan di kelas VIII SMP IT Al Huda Wonogiri.

Melibatkan Siswa (Require Learner
Participation)

Multimedia Interaktif diterapkan pada kelas eksperimen yang berjumlah 24 siswa. Sebelum multimedia interaktif diimplementasikan dalam kegiatan pembelajaran, terlebih dahulu dipersiapkan media pendukung dalam menggunakan multimedia interaktif seperti laptop dan sound system terutama untuk kelas eksperimen. Setelah itu guru memberikan arahan kepada siswa pada kelas eksperimen untuk menggunakan multimedia interaktif dalam kegiatan pembelajaran.

Metode yang diterapkan pada saat penyampian materi dengan multimedia interaktif ialah metode langsung. Pada multimedia interaktif terdapat latihan-latihan yang nantinya akan dijadikan bahan evaluasi.

Evaluasi (Evaluate)

Tahap yang terakhir pada penelitian pengembangan model ASSURE adalah evaluasi. Tahap evaluasi ini bertujuan untuk mengetahui keefektifan multimedia interaktif yang disusun pada mata pelajaran Bahasa Arab dibandingkan dengan media yang digunakan sebelumnya (BSE, buku cetak, gambar, dll), untuk meningkatkan penguasaan kosakata bahasa Arab sebelum dan sesudah menggunakan multimedia interaktif. Bentuk evaluasi berupa tes yang diberikan kepada siswa.

\section{PEMBAHASAN}


Pengetahuan kosakata sering dipandang sebagai alat penting bagi pelajar bahasa kedua karena kosakata terbatas dalam bahasa kedua menghambat komunikasi yang berhasil. Menggarisbawahi pentingnya akuisisi kosakata, Schmitt (2000) dalam Alqahtani (2015: 22) menekankan hal itu "Pengetahuan leksikal adalah pusat kompetensi komunikatif dan untuk perolehan bahasa kedua". Nation (2001) dalam Alqahtani (2015: 22) lebih lanjut menggambarkan hubungan antara pengetahuan kosakata dan penggunaan bahasa melengkapi satu sama lain. Pengetahuan tentang kosakata memungkinkan penggunaan bahasa dan, sebaliknya, penggunaan bahasa mengarah pada peningkatan pengetahuan kosa kata.

Kosakata adalah aspek kunci dalam pembelajaran bahasa. Hal tersebut menjadi persyaratan dasar dan prioritas awal dibandingkan dengan aspek linguistik lainnya. Dengan kata lain, marginalisasi peran kosakata dapat mempengaruhi penguasaan keterampilan bahasa. Telah diakui oleh Hunt \& Berglar (2005) dalam Baharudin \& Ismail (2015: 32) yang menyiratkan bahwa pengetahuan leksikal adalah inti dari pemahaman dan penggunaan bahasa. Tu'aymah (1986) dalam Baharudin \& Ismail (2015: 32) juga menyebutkan pengetahuan leksikal sebagai syarat utama dalam menguasai bahasa.

Pembelajaran kosakata adalah pusat dari penguasaan bahasa, baik bahasa pertama, kedua, atau asing. Perannya dalam pembelajaran bahasa kedua telah berkembang pesat dalam beberapa tahun terakhir, para spesialis sekarang menekankan perlunya pendekatan sistematis dan berprinsip pada kosakata baik oleh guru dan pelajar (Marianne, 2001: 285)
Hasil analisis studi pendahuuan, observasi, wawancara dan tahap analisis yang dilakukan menunjukkan bahwa penguasaan kosakata bahasa Arab siswa masih kurang. Siswa baru memiliki kosakata pada benda-benda yang ada di sekitar mereka, namun kosakata tersebut belum mampu dijadikan modal dalam berkomunikasi.

Diduga penguasaan kosakata siswa terjadi karena beberapa sebab diataranya; pertama, proses pembelajaran Bahasa Arab yang dilaksanakan masih monoton, dimana metode yang digunakan dalam pembelajaran hanya sebatas metode gramatika dan terjemah (tariqah al-qawaid wa at-tarjamah). Masalah seputar metodologi tidak hanya mengenai cara mentransfer pengetahuan secara langsung tetapi juga bagaimana mengarahkan siswa untuk melakukan belajar mandiri dan mencari informati. Karena itu, metode yang tepat akan memberikan motivasi para siswa untuk melanjutkan proses belajar mereka. Motivasi yang melekat dapat membimbing siswa untuk dapat mencari informasi baik secara individu maupun bimbingan oleh guru (Yusuf \& Wekke, 2018: 916).

Kedua, penggunaan bahan ajar buku cetak (al lughah al arabiyah) yang dominan, guru belum menggunakan fasilitas yang ada secara maksimal di dalam pembelajaran bahasa Arab. Penggunaan buku paket sebagai sumber materi dirasa belum memenuhi kebutuhan materi siswa. Oleh karena itu diperlukan inovasi dalam pemanfaatan media sebagai pendamping buku paket yang digunakan oleh guru, dan penunjang kebutuhan siswa.

Meningkatnya penggunaan program multimedia di sekolah (misalnya, melalui internet atau melalui program ad hoc) telah 
menyampaikan dukungan yang besar untuk pembelajaran individu, dalam arti bahwa hal tersebut memungkinkan siswa untuk mengakses berbagai jenis informasi pada saat yang sama (kata-kata, gambar, audio) dan dengan kecepatan mereka sendiri. Jadi, perancang program multimedia menghadapi tantangan tidak hanya mengadaptasi program dengan karakteristik pelajar, tetapi juga menyesuaikan persyaratan guna menjadi program-program efektif (Acha, 2009: 23).

Multimedia merupakan kegiatan interaktif yang sangat tinggi, mengajak pembelajar untuk mengikuti proses pembelajaran dengan memilih dan mengendalikan layar diantar jendela informasi dalam penyajian media. Dengan multimedia, berbagai gaya belajar pembelajar terakomodasi, seperti pembelajar auditori, visual, maupun kinestetik, sehingga pebelajar dapat memilih media yang sesuai dengan gaya belajar masing-masing (Anitah, 2014: 60-61).

Smaldino (2008: ) menambahkan beberapa manfaat dari penggunaan multimedia interaktif di kelas antara lain; Individualisasi. Komputer dan multimedia memungkinkan siswa mengendalikan laju dan urutan pembelajaran mereka, memberi mereka lebih banyak kendali sehingga menghasilkan menghasilkan penguatan tingkat tinggi.Kebutuhan khusus. Komputer dan multimedia efektif untuk pemelajar khusus, siswa dengan latar belakang budaya beraam, da siswa dengan ketidakmampuan. Kebutuhan khusus mereka bisa diakomodasi dan pengajaran berlanusng dalam kecepatan yang semestinya.

Pemantaun. Kemampuan komputer dalam menyimpan rekaman menjadikan pengajaran lebih terindividualisasi, guru bisa menyiapkan mata pelajaran individual untuk seluruh siswa dan memantau perkembangan mereka. Manajemen informasi. Komputer dan multimedia bisa mencakup dasar pengetahuan yang terus tumbuh yang terkait dengan ledakan informasi. Mereka bisa mengelola seluruh jenis informasi. Mereka bisa mengelola seluruh jenis infromasi (teks, grafis, audio, dan video). Pengalaman multisensorik. Komputer menyediakan berbagai macam pengalaman belajar dalam berbagai strategi pengajaran dan bisa berada pada tingkat pengajaran, perbaikan, atau pengayaan dasar. Partisipasi pembelajar. R dari model ASSURE tercapai dengan materi komputer dan multimedia karena mengharuskan para pembelajar untuk terlibat dalam kegiatan. Materi-materi ini membantu mempertahankan perhatian para siswa.

Proses pengembangan multimedia interaktif perlu dilakukan mengingat beberapa keunggulan dari media ini, Susilana dan Riyana menyebutkan beberapa keunggulan multimedia interaktif: melalui penggunaan multimedia interaktif memungkinkan peserta didik untuk melakukan kegiatan interaktif dengan software untuk menumbuhkan sifat keingintahuan peserta didik, mengatasi keterbatasan ruang dan waktu, serta rancangan sisi dan desain multimedia interaktif mengandung unsur teks, visual (grafis, video/film, animasi) dan audio dengan perbandingan $(7 \%, 55 \%, 38 \%)$ dengan maksud bahwa dalam media interaktif lebih dominan unsur visual, kemudian audio, dan teks yang paling minim (Susilana \& Riyana, 2009: 130131).

Dengan menggunakan model ASSURE, guru dapat memilih media yang sudah tersedia di internet atau bahkan membuat media yang sesuai 
dengan kebutuhan. Tahapan-tahapan pada model ASSURE sangat ringkas dan mudah untuk dikerjakan.

Smaldino (2008: 86) menjelaskan secara terperinci beberapa proses dalam pengembangan media dengan model ASSURE; Analisis Pembelajar, langkah pertama dalam merencanakan pelajaran adalah mengidentifikasi dan menganalisis karakteristik pembelajar yang terkait dengan hasil belajar. Bidang utama yang perlu dipertimbangkan selama analisis pelajar meliputi; (1) karakteristik umum termasuk deskipsi seperti usia, jenis kelamin, tingkat kelas, dan faktor budaya atau sosial ekonomi, (2) kompetensi khusus mengacu pada pengetahuan dan keterampilan dari pada yang dimiliki atau tidak dimiliki peserta didik, dan (3) gaya belajar, mengacu pada spektrum ciri-ciri psikologis yang mempengaruhi cara siswa Anda memahami dan merespons rangsangan yang berbeda,

Langkah kedua dalam model ASSURE adalah menyatakan standar dan tujuan pembelajaran untuk pelajaran tersebut. Hasil belajar apa yang diharapkan dicapai oleh setiap siswa? Penting untuk dicatat bahwa tujuan pembelajaran adalah pernyataan tentang apa yang akan dicapai oleh setiap pelajar, bukan bagaimana pelajaran akan diajarkan.

Langkah ketiga dalam memproduksi media yang mendukung pembelajaran melalui penggunaan teknologi. Langkah ini umumnya melibatkan tiga opsi: 1) memilih bahan yang tersedia, 2) memodifikasi bahan yang ada, atau 3) merancang bahan. Ketika bahan yang sudah jadi tidak tersedia, atau bahan yang keluar tidak dapat dengan mudah dimodifikasi, guru harus merancang bahan pelajarannya sendiri.
Langkah keempat yaitu memanfaatkan teknologi, media, dan materi. Guru perlu mempratinjau teknologi dan media yang dipilih sehubungan dengan tujuan pembelajaran. Tujuannya adalah untuk memilih bagian-bagian yang secara langsung selaras dengan pelajaran.

Langkah kelima melibatkan partisipasi pelajar. Ekonomi global saat ini menuntut siswa untuk memiliki pengalaman dan praktik menerapkan, menganalisis, mensintesis, dan mengevaluasi daripada sekadar mengetahui dan memahami informasi.

Langkah keenam mengevalusi. Komponen terakhir dari model ASSURE untuk pembelajaran yang efektif adalah mengevaluasi. Evaluasi sangat penting untuk pengembangan pengajaran yang berkualitas. Evaluasi juga mencakup penilaian strategi, teknologi, dan media. Apakah teknologi dan media membantu siswa dalam memenuhi tujuan pembelajaran ? Komponen kunci untuk evaluasi dan revisi pelajaran adalah masukan pembelajar atau umpan balik siswa mengenai strategi pengajaran.

Stahl (1999: 3) menyatakan bahwa pentingnya mempelajari kosakata, adalah: (1) alat bantu ekspresi dan komunikasi, (2) ukurannya secara langsung terkait dengan membaca pemahaman dan untuk berinteraksi antara yang lain.

Tingkat penguasaan kosakata siswa perlu diuji melalui pemberian tes. Tes dalam pembelajaran kosakata dapat dikelompokkan menjadi tes pemahaman dan tes penggunaan. Tes pemahaman lebih ditekankan pada pengukuran kemampuan siswa dalam memahami arti kosakata, sedangkan tes penggunaan lebih dititikberatkan pada kemampuan siswa 
menggunakan kosakata dalam suatu kalimat. Khusus untuk tes pemahaman kosakata, indikator kompetensi yang diukur dapat berupa arti kosakata, padanan kata, antonim kata, sinonim kata, pengertian kata, dan kelompok kata (Ainin, Tohir, \& Asrori, 2006: 13).

\section{SIMPULAN}

Hasil penelitian dan pengembangan tentang pengembangn multimedia interaktif pembelajaran bahasa Arab berbasis Adobe Flash dapat disimpulkan bahwa sistematika pengembangan multimedia tersebut diawali dengan studi pustaka dan studi lapangan. Selanjutnya model pengembangan multimedia interaktif dikembangkan menggunakan model ASSURE, dengan langkah sebagai berikut; 1) Analyze Learner (analisis karakteristik siswa), 2) State Objective (menetapkan tujuan pembelajaran), 3) Select Method Media and Materials (memilih metode, media dan bahan ajar) 4) Utilize Materials (memanfaatkan bahan ajar), 5) Require Learner Participation (melibatkan siswa dalam kegiatan belajar), dan 6) Evaluate and Revise (evaluasi dan revisi).

Penilaian ahli media terhadap multimedia pembelajaran intreraktif bahasa Arab berbasis Adobe Flash menunjukkan multimedia ini memiliki penilaian sangat baik. Jumlah skor yang diperoleh 229 dan rerata skor 4,60 yang kemudian dikonversikan dengan skala 5. Penilian dari ahli materi menunjukkan multimedia pembelajaran interaktif bahasa Arab ini memiliki penilaian baik. Jumlah skor yang diperoleh 362 dan rerata skor 3,97 yang kemudian dikonversikan dengan skala 5 sehingga diperoleh hasil baik.
Penilaian siswa terhadap multimedia pembelajaran intreraktif bahasa Arab berbasis Adobe Flash dinilai sangat baik dan rata-rata siswa tertarik belajar menggunakan multimedia tersebut. Data empirik hasil uji satu-satu menunjukkan multimedia interaktif termasuk kategori sangat baik dengan rerata skor 4,26. Pada uji coba kelompok kecil menunjukkan bahwa multimedia interaktif dalam kategori sangat baik dengan skor rerata 4,38 pada skala 5. Sedangkan hasil uji coba kelompok besar menunjukkan bahwa multimedia tersebut termasuk dalam kategori sangat baik dengan skor rerata 4,42 pada skala 5.

\section{DAFTAR PUSTAKA}

Acha, Joana. "The effectiveness of multimedia programmes in children's vocabulary learning", British Journal of Educational Technology, Vol. 40, No. 1, 2009, pp 2331.

Ainin, M. Tohir, M. \& Asrori, Imam. Evaluasi Dalam Pembelajaran Bahasa Arab. Malang: Misykat, 2006.

Alhirtani, Nahla A.K. "The Influence of Arabic Language Learning on Understanding of Islamic Legal Sciences-A Study in the Sultan Idris Education University", English Language Teaching, Vol. 11, No. 2, Januari, 2018, pp 55-66

Allen, Virginia French. Techniques in teaching Vocabulary. New York: Oxford University Press, 1983.

Alqahtani, Mofareh. "The Importance Of Vocabulary In Language Learning And How To Be Taught", International Journal of Teaching and Education, Vol. 3, No. 3, April, 2015, pp 21-34.

Anitah, Sri. Media Pembelajaran. Surakarta: Sebelas Maret University Press, 2014.

Baharudin, H. \& Ismail, Z. "Learning Strategies of Arabic Language Vocabulary for PreUniversity Students' in Malaysia", English Language Teaching, Vol. 11, No. 10, 2015, April, pp 32-38. 
Chang, Yujie. "How to Use Multimedia in College English Vocabulary Teaching", International Conference on Sports, Arts, Education and Management Engineering: Advances in Social Science, Education and Humanities Research, Atlantis Press , Vol. 105, 2017, pp 294297.

Coady, James \& Huckin, Thomas. Second Language Vocabulary Acqusition. New York: Cambridge University Press, 1997.

Daryanto. Media Pembelajaran Perannanya Sangat Penting Dalam Mencapai Tujuan Pembelajaran. Yogyakarta: Gava Media, 2013.

Dick, Walter. Carey, Lou. and Carey, J O. The Systematic Design of Instruction (Seventh Edition). New Jersey: Pearson Education, 2009.

Faryadi, Qais. "Techniques of Teaching Arabic as a Foreign Language through Constructivist Paradigm: Malaysian Perspective", Februari, 2007, pp 1-20.

Ghanbaran, S. and Ketabi, Saeed. "Multimedia Games and Vocabulary Learning", Theory and Practice in Language Studies, Vol. 4, No. 3, Maret, 2014, pp 489-496.

Kenedy, M J. Rodger, W J. Romig, J E. Lloyd, J W. Brownell, M T. "Effects of a Multimedia Professional Development Package on Inclusive Science Teachers' Vocabulary Instruction", Journal of Teacher Education, Vol. 68, No. 2, 2017, pp 213-230.

Khiyabani, H . Ghonsooly, B. And Ghabanchi, Z. "Using Multimedia in Teaching Vocabulary in High School Classes", Journal of Advances in English Language Teaching, Vol. .2, No.1, 2014, Januari, pp $1-13$.

Laufer, B. \& P. Nation. A vocabulary size test of controlled productive ability.Language Testing 16, 33-51.

Marianne, Celce M. Teaching English as a Second of Foreign Language. United States of America: Thomson Learning, 2001.

Maskor, Z M. Baharudin, H. Aqsha, L M. and Yusuf, N K. "Teaching and Learning Arabic Vocabulary: From a Teacher's
Experiences", Creative Education, Vol. 7, Maret, 2016, pp 482-490.

Mu'in, Abdullah. Analisis Kontrastif Bahasa Arab \& Bahasa Indonesia Telaah Fonetik Dan Morfologi. Pekalongan: Duta Media Utama, 2015.

Mustofa, Syaiful. Strategi Pembelajaran Bahasa Arab Inovatif. Malang: Maliki Press, 2011.

Pribadi, Benny. Model ASSURE Untuk Mendesain pembelajaran Sukses. Jakarta: Dian rakyat, 2011.

Rivers, Wilga M. Interactive Language Teaching. New York: Press Syndicate of the University of Cambridge, 1987.

Sahrir, M S. "A Study On Malaysian Language Learners' Perception Towards Learning Arabic Via Online Games", Journal of Language Studie, Vol. 11, No. 3, September, 2011, pp 129 - 145.

Shao, Jing. "A Study of Multimedia Applicationbased Vocabulary Acquisition”, English Language Teaching, Vol. 5, No. 10, Agustus, 2012, pp 202-207.

Silverman, R. \& Hines, S. "The Effects of Multimedia-Enhanced Instruction on the Vocabulary of English-Language Learners and Non-English-Language Learners in Pre-Kindergarten Through Second Grade", Journal of Educational Psychology, Vol. 101, No. 2, Agustus, 2009, pp 305-314.

Smaldino, Lowther, \& Russell. Instructional Technology And Media For Learning. New Jersey: Pearson, 2008.

Stahl, Steven.. A Vocabulary Development: The Cognitive Foundations of Learning to Read. Cambridge: Brookline Books, 1999.

Sudijono, Anas. Pengantar Evaluasi Pendidikan, Jakarta: Raja Grafindo Persada, 2005.

Sugiyono. Metode Penelitian Pendidikan (Pendekatan Kuantitatif, Kualitatif Dan $R \& D)$. Bandung: Alfabeta, 2011.

Susilana, Rudi. \& Riyana, Cepi. Media Pembelajaran Hakikat, Pengembangan, Pemanfaatan, dan Penilaian, Bandung: Wacana Prima, 2007. 
Ren, Mei. "English vocabulary teaching based on multimedia technology", Computer Modelling \& New Technologies, Vol. 17, No. 5, Oktober, 2013, pp 263-265.

Tarigan, Henry Guntur. Pengajaran Kosakata. Bandung: Angkasa, 2011.

Thornbury, Scott. How to Teach Vocabulary. Essex: Pearson Education Limited, 2002.

Wa Muna. Metodologi Pembelajaran Bahasa Arab (Teori Dan Aplikasi). Yogyakarta: Teras, 2011.

Xue Shi. "Application of Multimedia Technology in Vocabulary Learning for Engineering Students", International Journal of Emerging Technologies in Learning, Vol. 12, No. 1, 2017, Oktober, pp 21-31.
Yusuf, M. dan Wekke, I S. "Teaching and Learning Arabic and Quran through Ecletic Method in Islamic School", International Journal of Pure and Applied Mathematics, Vol. 119, No. 18, Janauri, 2018, pp 915 - 926

Zulhanan. Teknik Pembelajaran Bahasa Arab Interaktif. Jakarta: Raja Grafindo Persada, 2014.

Westomi, J. Ibrahim, N. \& Sukardjo, M. "Pengembangan Paket Modul Cetak Mata Pelajaran Pendidikan Agama Islam (PAI) untuk Siswa SMA Negeri 1 Wangi-wangi Kabupaten Wakatobi”. JTP - Jurnal Teknologi Pendidikan, Vol. 20, No. 2, Agustus, 2018, pp 138-151. 